\title{
Success Factors of Clinical Risk Management - Measuring a Safety Index
}

\author{
Peter Gausmann ${ }^{*}$, Marsha Fleischer \\ From Safety in hospitals: from strategy to implementation Annual Scientific Meeting 2015 \\ Graz, Austria. 29-30 September 2015
}

\section{Background}

The political, legal and insurance-related requirements for hospitals, out-patient treatment centers and other healthcare companies in Germany and European countries are constantly increasing. At the same time, however, evidence for the effectiveness and establishment of clinical measures for patient safety is becoming ever more important [1].

Since 1994, the GRB - Gesellschaft für Risiko-Beratung $\mathrm{mbH}$ has been providing advice to hospitals and other healthcare facilities on how to implement risk management measures in clinical processes in order to ensure a safe patient care. For quite a long time, the GRB has dealt with defining suitable parameters for patient safety. In the meantime, it has developed a model-based safety index, which enables a healthcare company to make the maturity level measurable.

\section{Material and methods}

Results from one of Germany's largest healthcare-loss databases and specifically developed claim-based prevention measures and performing safety and risk analyses in different specialist/service areas in healthcare companies serve as a basis for determining a safety index [2].

The development of the index aimed at measuring patient safety is based on the modified Swiss cheese model by Reason [3].

The following parameters are relevant for the calculation of the index:

1. Index-related prevention measures

2. Weighting of the potential risk in case that a prevention measure has not been fulfilled (severity of potential damage and probability of occurrence)

3. Fulfillment level of a prevention measure

\footnotetext{
* Correspondence: peter.gausmann@grb.de

GRB Gesellschaft für Risiko-Beratung mbH, Detmold, North Rhine-Westfalia, Germany
} provided the original work is properly cited. The Creative Commons Public Domain Dedication waiver (http://creativecommons.org/ publicdomain/zero/1.0/) applies to the data made available in this article, unless otherwise stated. analysis in surgery rooms including the interface anesthesia in three different clinics (Source riskala ${ }^{\circledR}$ GRB)

\begin{tabular}{|c|c|c|c|c|}
\hline Safety Categories & Average & $\begin{array}{c}\text { Clinic } \\
\text { A }\end{array}$ & $\underset{\text { B }}{\text { Clinic }}$ & $\underset{\mathrm{C}}{\mathrm{Clinic}}$ \\
\hline Patient information & 98 & 100 & 100 & 94 \\
\hline Treatment anesthesia & 95 & 87 & 97 & 100 \\
\hline Documentation anesthesia & 100 & 100 & 100 & 100 \\
\hline Documentation surgery & 81 & 79 & 75 & 89 \\
\hline Medical specialist standard & 99 & 100 & 100 & 98 \\
\hline Hygiene management & 72 & 72 & 58 & 85 \\
\hline $\begin{array}{l}\text { Ensuring identity/ } \\
\text { Avoidance of patient } \\
\text { misidentification }\end{array}$ & 57 & 45 & 62 & 65 \\
\hline Medication management & 73 & 75 & 62 & 83 \\
\hline Organization anesthesia & 89 & 91 & 76 & 100 \\
\hline Organization recovery room & 95 & 85 & 100 & 100 \\
\hline Organization surgery room & 80 & 67 & 79 & 93 \\
\hline Safety index total & 85 & 82 & 83 & 92 \\
\hline
\end{tabular}

\section{Results}

The parameters described above are applied in a special formula. The index determines values between 0 and 100. 100 means maximum safety and 0 means maximum risk. The index can be determined after a safety and risk analysis for healthcare facilities. It can be ascertained for the examined area, in detail for accounted safety categories and as assessment comparison (Table 1).

\section{Conclusions}

The index is an efficient instrument with which the safety profile of a healthcare company can be made transparent both internally and externally in accordance with the continuous process of improvement, and it can be used effectively for business management.

Table 1. Overview: safety index after safety and risk 


\section{Competing interests}

The authors have the following competing interests:

Employment relationship or executive position: Risk consultant Gesellschaft für Risiko-Beratung mbH, Detmold.

Consulting activity: Risk consultant for clinical risk management and risk-

adjusted quality management systems in healthcare sector.

Published: 30 October 2015

\section{References}

1. Gausmann P: Safety Clip. New national health target patient safety. $B D C$ Member Magazine Passion Chirurgie, Special 2014.

2. Fleischer M: Safety Clip. riskala.INDEX: Patient safety index. BDC Member Magazine Passion Chirurgie 2013.

3. Reason J: Human error: models and management. British Medical Journal 2000, 320(7237):768-770.

doi:10.1186/2056-5917-1-S1-A19

Cite this article as: Gausmann and Fleischer: Success Factors of Clinical

Risk Management - Measuring a Safety Index. Safety in Health 2015

1(Suppl 1):A19.

\section{Submit your next manuscript to BioMed Central} and take full advantage of:

- Convenient online submission

- Thorough peer review

- No space constraints or color figure charges

- Immediate publication on acceptance

- Inclusion in PubMed, CAS, Scopus and Google Scholar

- Research which is freely available for redistribution

Submit your manuscript at www.biomedcentral.com/submit
(Ciomed Central 